\title{
Materno-foetal exchanges and utilisation of nutrients by the foetus: comparison between species
}

\author{
Marie-Christine PÈRE* \\ Institut National de la Recherche Agronomique, \\ Unité Mixte de Recherches sur le Veau et le Porc, 35590 Saint-Gilles, France
}

(Received 25 May 2002; accepted 26 December 2002)

\begin{abstract}
Several general features of nutrient uptake and utilisation by foetuses are similar among mammalian species. Nevertheless, there are also differences linked mainly to differences in placental permeability. Glucose and lactate are the main energetic substrates of the foetus. In normal conditions, the oxidation of carbohydrates accounts for about 75, 60 and $50 \%$ of oxygen uptake in the foetal pig, foal and lamb, respectively, and acetate accounts for about $10 \%$ in ruminants. Acidic amino acids are synthesised by the foetus, whereas neutral and basic amino acids are transported from the placenta. As shown by the high urea level in foetal blood, amino acids are partly involved in the oxidative metabolism of foetuses; their contribution is higher in ruminants than in humans, horses and pigs. Fatty acids cross the haemochorial placenta of rodents, rabbits and primates, and are incorporated into the foetal lipids, whereas their uptake by ruminant, pig and horse foetuses is very low.
\end{abstract}

materno-foetal exchange / mammal / carbohydrate / fatty acid / amino acid

\section{INTRODUCTION}

There are important differences between species in their development stage and energy stores at birth (Tab. I). Fat content varies considerably, with the highest value found in humans and the lowest in pigs and rats. The fat/protein ratio remains low and relatively constant in rats and pigs, whereas it increases dramatically during the last quarter of pregnancy in humans and rabbits (Fig. 1). Mammalian foetuses accumulate glycogen to levels two to three times those of adults, mainly in muscle and liver. Glycogen appears relatively late in pregnancy (Fig. 2). The rate and kinetics of glycogen synthesis before birth differ greatly between species. In species with a relatively long gestation (humans and sheep), liver glycogen begins to accumulate relatively early at

\footnotetext{
* Correspondence and reprints

E-mail: pere@st-gilles.rennes.inra.fr
} 
Table I. Fat and glycogen stores in the neonates of several mammalian species (adapted from Susa [62]).

\begin{tabular}{lcccc}
\hline Species & $\begin{array}{c}\text { Birth weight } \\
\mathrm{g}\end{array}$ & $\begin{array}{c}\text { Lipids } \\
\mathrm{g} \cdot \mathrm{kg}^{-1} \mathrm{BW}\end{array}$ & $\begin{array}{c}\text { Muscle glycogen } \\
\mathrm{g} \cdot \mathrm{kg}^{-1} \mathrm{BW}\end{array}$ & $\begin{array}{c}\text { Liver glycogen } \\
\mathrm{g} \cdot \mathrm{kg}^{-1} \mathrm{BW}\end{array}$ \\
\hline Human & 3500 & 160 & 7.5 & 3.8 \\
Guinea-pig & 100 & 110 & 4.5 & 3.5 \\
Rabbit & 50 & 58 & 2.3 & 2.7 \\
Sheep & 4500 & 30 & 8.8 & 2.2 \\
Monkey & 500 & 20 & 7.5 & 2.5 \\
Rat & 5 & 11 & 1.8 & 5.8 \\
Pig & 1300 & 11 & 20.9 & 2.1 \\
\hline
\end{tabular}

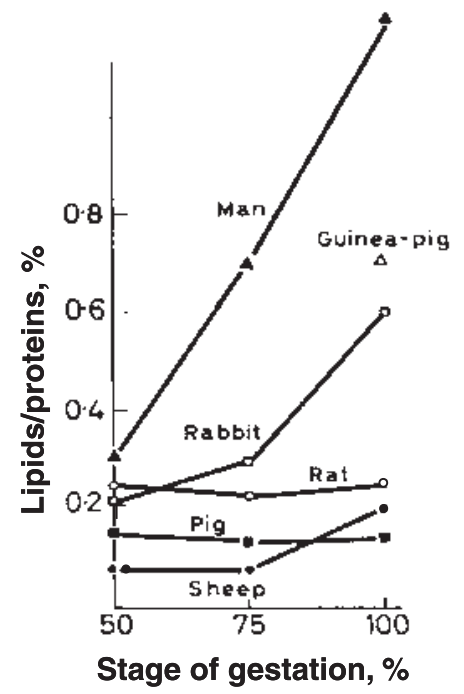

Figure 1. Body lipid/protein changes in several species before birth [1].

a rather steady rate $\left(2 \mathrm{mg} \cdot \mathrm{g}^{-1} \cdot \mathrm{day}^{-1}\right)$, whereas in species with a shorter gestation (pigs and rats), the rise takes place during the last fifth of gestation and occurs at a high rate $\left(10-40 \mathrm{mg} \cdot \mathrm{g}^{-1} \cdot \mathrm{day}^{-1}\right)[1]$. The glycogen stores are essential for the maintenance of body temperature after birth, and they are considerably reduced during the first hours

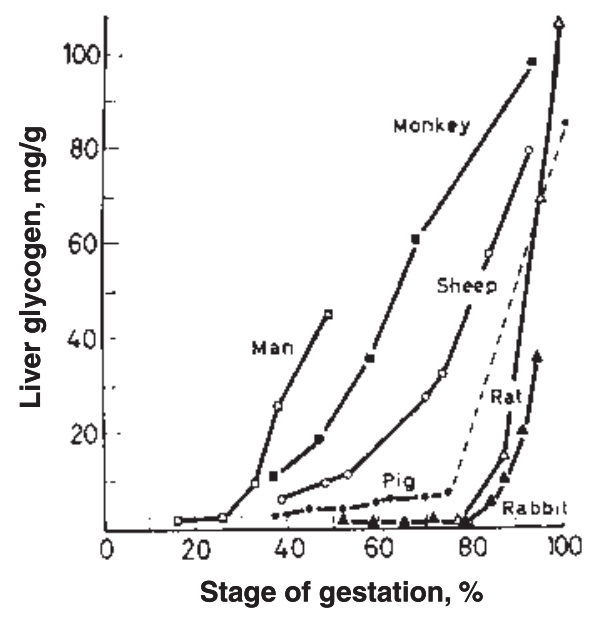

Figure 2. Variation of liver glycogen content in several species before birth [1].

of life. This is especially the case in pigs where liver glycogen is crucial for the survival of the neonate [2]. Differences in the accumulation of fat and glycogen stores between species suggest that the latter also differ in the materno-foetal exchanges and metabolism of substrates. These exchanges depend on several aspects, mainly blood flow across the uterine and umbilical circulation, relative substrate concentration in 
maternal and foetal blood, and placental permeability. Uterine blood flow steadily increases as pregnancy proceeds, which partly adapts the substrate supply to the requirements of the foetuses [3]. Permeability of the placenta mainly depends on its structure, and the haemochorial placenta of primates and rodents is classically opposed to the epitheliochorial placenta of horses, ruminants and pigs which is less permeable.

Prolonged in vivo studies on maternofoetal exchanges in small animals like rodents are difficult to perform because of their size, which limits foetus manipulations. Owing to ethical problems, most of the measurements in humans have been carried out around parturition. Sheep have therefore been extensively utilised because it is possible to put catheters into the maternal and foetal circulation and obtain prolonged measurements in the conscious unstressed animal in normal or experimentally modified conditions. There are less studies on bigger animals because of their higher cost, and on pigs which are prone to abortion when manipulating their uterus. But most of the experiments were conducted during the last third of pregnancy. This review deals with the comparison of materno-foetal exchanges of substrates and their utilisation by the foetus in different species.

\section{CARBOHYDRATES}

\subsection{Glucose}

Glucose is transferred to the foetus via a carrier-mediated facilitated diffusion system which is stereospecific $[4,5]$, with saturation of the carrier mechanism at high maternal and foetal glucose concentrations [6]. Glucose transporters include the GLUT1 and GLUT3 isoforms [7]. GLUT1 is the primary isoform involved in humans, whereas GLUT3 becomes increasingly prominent as gestation progresses in other mammalian species such as the mouse, rat and sheep [8]. The GLUT4 glucose transporter was shown to be colocalised with insulin receptors in human and rodent haemochorial placentas, but its significance remains to be elucidated [9]. In all the species studied, glucose concentration is lower in the foetal than in the maternal blood (Fig. 3). However, the difference is much smaller in humans and monkeys than in ruminants and pigs, in agreement with the higher efficiency of the primate placenta. In pigs, for instance, maternal glycaemia is 2.5 times higher than in the foetus [10-12]. Figure 3 also shows that as maternal glycaemia increases, foetal glycaemia and materno-foetal differences increase. This is the case after meal intake in the pig where the slope of the relationship between foetal and maternal glycaemia is about 0.30 [13]. In contrast, fasting $[14,15]$ or insulin perfusion [16] in sheep decreases glucose umbilical uptake. This induces the foetus to alter its metabolism and to require less exogenous glucose, very likely through insulin regulation [17]. Indeed, foetal insulinaemia decreases during fasting [18], whereas insulin infusion into the foetus increases its glucose uptake [19]. However, by using hyperinsulinaemic euglycaemic clamps in

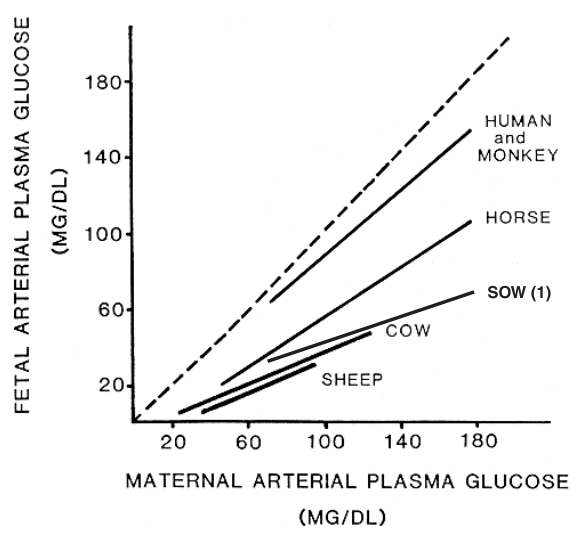

Figure 3. Relationship between maternal and foetal glycaemia in several species (from Battaglia and Meschia [21] and (1) Père [13]). 
foetal lambs, DiGiacomo and Hay [20] suggested that the transfer of glucose to the foetus by the uteroplacenta was regulated by foetal glucose concentration rather than by foetal insulin concentration.

Under normal physiological conditions, uterine glucose uptake is much higher than the net flux of glucose from the placenta to the foetus [21]. In ewes, for instance, uterine glucose uptake is more than three times higher than umbilical glucose uptake [22, 23], and Ferrell and Reynolds [24] estimated that the glucose uptake by the foetal calf amounted to only $12 \%$ of the glucose uptake by the uterus. This is primarily due to a large utilisation rate of glucose by the placenta [23]. In all species, glucose is the main substrate of foetal oxidative metabolism, but its relative importance varies according to the species. High respiration quotients for glucose were generally found at the uterine level: 1.13 in cows [25], 0.79 [26] and 0.86 [27] in pigs, 0.41 [28] and 0.76 in sheep [29]. At the umbilical level, results obtained in well-fed animals near term show that if it were totally oxidised, glucose would account for about $40 \%$ of total foetal oxygen uptake in the foetal pig [26], 40 to $60 \%$ in lambs $[17,28,30], 57 \%$ in calves [31], 68\% in foal [32], 81\% in humans [17]. Glucose is however not completely oxidised. The oxidation rate of glucose carbon has been measured in several species by using labelled glucose. Glucose accounts for a higher proportion of oxygen consumption in the foetal foal (about 40\% [33]) or foetal pig (35-40\% [34]) than in the foetal lamb (about 30\% [35-37]) during late gestation. In the case of maternal hypoglycaemia induced by fasting, the contribution of exogenous glucose to foetal requirements is reduced to approximately half of the normal value in sheep [30], its foetal utilisation is decreased, and foetal gluconeogenesis is increased $[15,38]$. It was even shown by Hodgson et al. [39] that $44 \%$ of the glucose used by twin foetuses from well-fed ewes was provided by foetal gluconeogenesis. Gluconeogenesis was also observed just before delivery in the foetal lamb [40]. According to Levitsky et al. [41], gluconeogenesis from lactate occurs in the baboon foetus during the last quarter of pregnancy in the maternal fed and fasted states. On the contrary, endogenous production of glucose by the foetal foal [33], the foetal pig [34], or the foetal rat [42] is negligible in the fed state. However, increased glycogenic capacity towards term, related to the prepartum rise in endogenous cortisol, was demonstrated in the foetal foal [43], sheep [40], and pig [44].

As foetuses grow very fast during the last part of pregnancy, their glucose requirements become increasingly important. Physiological and metabolic adaptations of the mother are then required to face to this situation. In all the species studied (humans, rat, guinea-pig, rabbit, sheep), the rate of glucose utilisation by the conceptus amounts to $30-50 \%$ of the overall glucose utilisation by the mother in late pregnancy [45] (Fig. 4). In the meantime, glucose utilisation by maternal tissues is lower than in nonpregnant females. This suggests that pregnant animals decrease glucose utilisation by their own tissues in order to supply it in greater amounts to the pregnant uterus. Maternal tissues must therefore use fuels other than glucose, like free fatty acids, glycerol or glucogenic amino acids, to meet their energetic requirements. In the late pregnant sow, increased levels of blood alanine [46], or of plasma free fatty acids [47] like in other species, support this hypothesis.

Relative hypoglycaemia and hyperinsulinaemia are found in many species after an overnight fast or in the postabsorptive period during the last part of gestation. This suggests that maternal tissues may be less sensitive to insulin than in nonpregnant females or during the earlier parts of pregnancy. This is another way for the mother to spare glucose for her foetuses. Glucose tolerance tests showed that in rats, an insulin resistance develops after 16 days 
Figure 4. Utilisation rates of glucose in pregnant and non-pregnant females in several species (from Leturque et al. [45]).

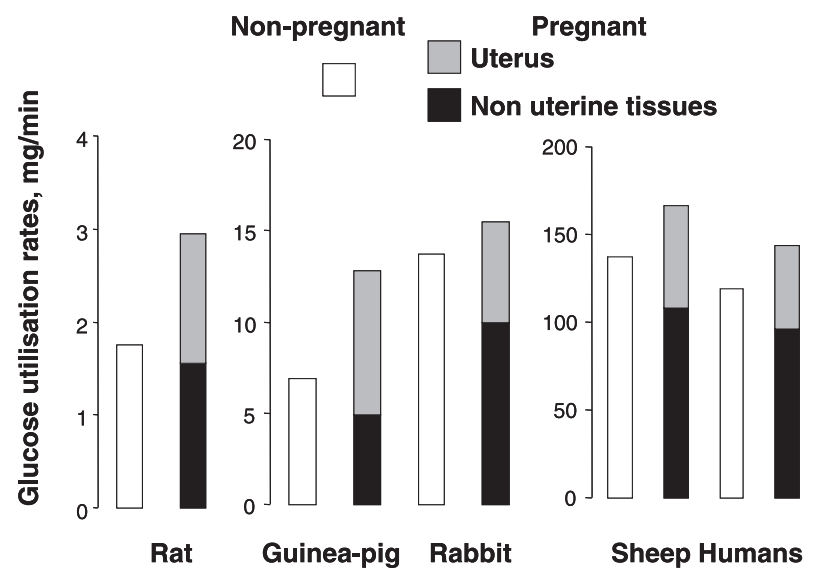

of pregnancy and becomes maximal at 19 days [48]. By using euglycaemic hyperinsulinaemic clamps with rats and rabbits, Leturque et al. [49] and Hauguel et al. [50] demonstrated that insulin was less efficient to stimulate utilisation or to depress hepatic production of glucose during the last third of pregnancy. A decreased insulin sensitivity was also shown in late pregnant sows by measuring glucose tolerance (Tab. II) and variation of plasma glucose and insulin around the meal [47]. However, this adaptation develops from 12 weeks of gestation only (pregnancy duration: 114 days). Moreover, It is more limited than in other species and occurs without any increase in insulin levels. This characteristic may help explain why new-born pigs have low body fat stores.

Several experiments based on induction of gestational diabetes in sows were performed to increase glucose uptake by foetuses and enhance their glycogen and fat stores at birth in order to improve their survival. Maternal diabete was induced by intravenous injections of alloxan [51-54] or streptozotocin [55] in 70-80-day pregnant sows. Increased glycaemia to about $5 \mathrm{~g} \cdot \mathrm{L}^{-1}$ and higher plasma free fatty acids $(\times 3)$ were observed in sows $[51,55,56]$. Similar effects were found in their foetuses at 112 days ( 1.31 vs. 0.48 g glucose and 562 vs. $408 \mu$ Eq FFA per L plasma; Kasser et al. [56]). Foetal livers were heavier (136 to $180 \%$ ) without live weight change $[51,55]$. In most studies, the glycogen level in the liver was increased by 30 to $200 \%$, depending on the treatment, whereas the glycogen content in muscle was unaffected. Fatter livers in foetuses from diabetic sows were also reported [55]. The lipid content in the carcass was 2 to 3 times higher than in control foetuses $[54,55]$. Adipose tissue of the foetuses from treated sows was thicker, more

Table II. Effect of experimental stage on glucose half-life in pregnant and non-pregnant sows (min) after a $0.5 \mathrm{~g} \cdot \mathrm{kg}^{-1}$ glucose injection [47].

\begin{tabular}{lccccc}
\hline & \multicolumn{5}{c}{ Stage, $\mathrm{d}$} \\
\cline { 2 - 6 } Physiological status & 35 & 71 & 84 & 96 & 108 \\
\hline Pregnant & 9.6 & 10.8 & 11.5 & 12.2 & 14.5 \\
Non-pregnant & 8.6 & 9.1 & 10.4 & 9.3 & 10.0 \\
\hline
\end{tabular}


lipid-filled, had an increased fat cell size and a larger number of fat cell clusters than in the control group [53]. Subcutaneous adipose tissue lipogenesis and the associated enzymes were considerably increased. This supports the concept that in pigs, de novo fatty acid synthesis is stimulated by diabetic pregnancies $[52,54]$, and demonstrates that in sows, prolonged increased maternal glycaemia during the last third of pregnancy stimulates foetal glucose uptake, glycogen deposition in the liver and lipogenesis in the adipose tissue.

\subsection{Lactate}

In most species, lactate concentration in blood plasma is 2- to 3-fold higher in the foetus than in the dam. In the pig, after an overnight fast, it amounts to 2.29 and $0.90 \mathrm{mmol} \cdot \mathrm{L}^{-1}$ in the foetal umbilical vein and the maternal arterial blood, respectively [11]. A higher lactate level in the uterine vein relative to the artery was demonstrated in several species [10, 25, 57-60], showing a net uptake of lactate by the mother from the uterus. Lactate is produced from glucose by the placenta under aerobic conditions and is carrier-mediated transferred to the foetus [21]. Similarly to glucose, lactate concentration in foetal pig blood increases after the meal [61], suggesting a higher lactate production in these conditions. The contribution of lactate to foetal metabolism amounts to one-third to one-half that of glucose in most species [17]. It is minimal in the human foetus but represents $25 \%$ of the carbon supply to foetal sheep [62]. According to Hay et al. [36], 70\% of the lactate utilised by the foetal lamb is oxidised. Umbilical uptake of lactate is significant in foal foetuses older than 290 days, but not in the younger animals [33]. If completely oxidised, it would then account for $10-15 \%$ of the umbilical $\mathrm{O}_{2}$ uptake. Recent results from Fowden et al. [34] on fed sows show that the contribution of lactate should be higher in pigs than in other species, since its umbilical uptake represents about $85 \%$ that of glucose, and if completely oxidised, 20-30\% of the umbilical $\mathrm{O}_{2}$ uptake.

\subsection{Fructose}

Fructose is quantitatively the main carbohydrate of foetal blood in all the species studied [11, 30, 63, 64], whereas it is almost absent from the maternal blood. Its concentration is 2-3 times higher than that of glucose. Fructose is produced by the placenta from glucose and transferred to the foetus, but no significant difference between fructose concentration in the umbilical venous and arterial blood was shown in the sheep [30], cow and horse [64] or pig [11, 63]. Its metabolic fate remains relatively unknown. Fructose may be involved in the synthesis of nucleic acids [65]. It could also be used as an energetic fuel during fasting since fructose concentration in blood from the ovine foetus drops when the mother is starving [17]. Little incorporation of $\left[{ }^{14} \mathrm{C}\right]$-fructose in foetal liver glycogen was found in vitro [66]. $\left[\mathrm{U}_{-}{ }^{14} \mathrm{C}\right]$ fructose infused to foetal lambs was metabolised to lactate plus $\mathrm{CO}_{2}$ in both the placenta and the foetus, but its utilisation rate by the foetus represented about $5 \%$ of the $\mathrm{CO}_{2}$ produced by the foetal sheep only [67].

Oxidation of carbohydrates could then account for $75 \%$ of the oxygen taken up by the foetal piglet [34], whereas lower values were obtained in the foetal foal $(64 \%$ [33]) and lamb (50\% [35-36]) (Tab. III).

\section{LIPIDS}

All foetuses are able to synthesise lipids, but the great variation in lipid content of new-borns between species suggests that the placental transfer of fatty acids and/or their synthesis rate by foetuses also differ. 
Table III. Supply of carbon as carbohydrates and carbon requirements for oxidation and glycogen deposition in the foetal piglet, foal and lamb in late pregnancy [34].

\begin{tabular}{lcccc}
\hline & \multicolumn{2}{c}{ Supply $\left(\mathrm{g} \cdot \mathrm{day}^{-1} \cdot \mathrm{kg}^{-1}\right)$} & \multicolumn{2}{c}{ Requirements $\left(\mathrm{g} \cdot \mathrm{day}^{-1} \cdot \mathrm{kg}^{-1}\right)$} \\
& Glucose & Lactate & Oxidation & Glycogen \\
\hline Piglet & 4.28 & 1.70 & 5.82 & 1.40 \\
Foal & 3.86 & 0.64 & 4.98 & 0.20 \\
Lamb & 2.99 & 0.79 & 5.08 & 0.40 \\
\hline
\end{tabular}

\subsection{Fatty acids, ketone bodies and glycerol}

In all mammalian species, non-essential fatty acids can be synthesised de novo, whereas essential fatty acids must be transferred from the mother to the foetus, since the long-chain polyunsaturated fatty acid composition of brain phosphoglycerides is similar in various species that differ for many traits [17]. In guinea-pigs and women fed diets containing linoleic and linolenic acids labelled with ${ }^{14} \mathrm{C}$, Crawford et al. [68] found an increased proportion of radioactivity in the long-chain polyunsaturated fatty acids within the phospholipids from the mother to placenta or foetal cord blood, to foetal liver, and to foetal brain. It seems that a multiple processing system increases fatty acid chain length and degree of polyunsaturation from the mother to foetal brain [68]. Placenta and foetal tissues thus appear indispensable in the synthesis of these essential brain compounds.

In species with a less permeable placenta, the levels of FFA and ketoacids in foetal blood are low and not correlated with the maternal levels [61, 69]. Their uptake does not represent a significant energy source for the gravid uterus of sheep [70], cows [64], mares [64] or sows [10, 61]. In experiments involving ewes [71, 72] or sows $[73,74]$ injected with labelled fatty acids, only trace amounts of these fatty acids crossed the placenta during late gestation.
Elphick et al. [73] demonstrated that most of the umbilical fatty acid uptake was not directly derived from maternal FFA, and metabolism of fatty acids was demonstrated in the porcine placenta $[75,76]$. This may partly explain the low fat accumulation in new-born lambs and pigs. The increase of plasma FFA in pregnant sows through fasting did not affect [77] or only slightly increased [54] the percentage of carcass lipid of their foetuses. Père [61] showed that some extraction of fatty acids by the sow uterus and a small but significant umbilical uptake occurred before the meal, when the level of fatty acids in sow plasma was elevated, but this was no more the case after the meal. Though in limited amounts, some fatty acids cross the placental barrier of the pig since piglets sacrificed at birth, before they had the opportunity to suckle, were fatter and had a higher content of linoleic acid when the maternal pregnancy diet was supplemented with corn oil [78] or sunflower oil [79], or a higher content of lauric and myristic acids when the diet was supplemented with copra oil [79] (Tab. IV). But FFA and ketoacids certainly have a minor importance in the energy supply to the ruminant and porcine foetuses. Uterine and foetal uptake of acetate was also shown in ruminants. Foetal umbilical venous acetate concentration is proportional to the maternal acetate concentration in sheep [80] and in cows [31]. Acetate could account for $10 \%$ [80] and $16 \%$ [31] of the oxygen uptake in the foetal lamb and calf, respectively. 
Table IV. Effect of the addition of 3\% copra or sunflower oil in the sow pregnancy diet on the lipid content and fatty acid composition of piglets at birth [79].

\begin{tabular}{lccc}
\hline Diet & Control & 3\% copra oil & 3\% sunflower oil \\
\hline Lipids in the carcass, \% & 1.22 & 1.44 & 1.66 \\
Fatty acids in \% of total fatty acids & & & \\
C 12:0 & 0.00 & 0.16 & 0.00 \\
C 14:0 & 3.72 & 7.20 & 3.29 \\
C 18:2 & 4.42 & 4.80 & 7.97 \\
\hline
\end{tabular}

Similarly to glucose, the utilisation of acetate by the uteroplacental tissue is much higher than that of the foetus in cows [31].

In species with a more permeable placenta like the rabbit [81-84], guinea-pig $[85,86]$, rat [87-89], rhesus monkey [90] and humans [91-93], FFA and ketoacids are readily transferred from the mother to its foetuses. Fatty acids can cross the rabbit placenta in either direction [82]. In guinea-pigs, when FFA were increased on the foetal side by FFA perfusion, their net placental transfer from the mother to its foetuses tended to fall, and when they exceeded those of the mother, they were transferred to the mother [86]. Doubling the blood level or FFA in pregnant does through a 48-h fast increased the fat stores of their foetuses by 80-100\%, which suggests that increased amounts of fatty acids crossed the placenta [81]. FFA are mainly incorporated into lipids and are therefore not a major energy source for foetal tissues [89, 94]. In species with large lipid stores (humans, guineapigs), the transfer of FFA becomes inadequate near term and de novo lipid synthesis increases [62]. Unlike fatty acids, ketoacids could be an alternative fuel in the placenta and some foetal tissues of rats and humans and thus spare glucose [94].

In rats and rabbits, placental transfer of glycerol was demonstrated by intravascular injection of $\left[{ }^{14} \mathrm{C}\right]$-glycerol into the mother in late pregnancy [42]. It may contribute to producing glucose and increasing glycogen reserves near term. The transfer of glycerol across the uterus was also shown after an overnight fast in pigs, but it seemed to be very limited [61]. Sabata et al. [92] did not find any glycerol passage from the mother to the foetus during delivery in women.

\subsection{Triglycerides}

Triglyceride transfer was also shown in guinea-pigs and rats. In guinea-pigs, approximately $7 \%$ of the maternal plasma triglycerides are transferred to the foetuses [95]. VLDL-triglycerides are not transferred intact, but are first hydrolysed by an intracellular placental lipoprotein lipase $[95,96]$. Lipoprotein lipase activity has been demonstrated in the rat, rabbit and human placenta $[97,98]$. The rate of transfer of the derived fatty acids to the foetal circulation is limited by the rate of triglyceride lipolysis rather than by reesterification [96].

\section{AMINO ACIDS}

The amino acid composition of carcasses of the foetus and adult are similar in the rat, and similar to that in the pig and the chick. Relative amino acid requirements are, therefore, the same at different ages and among species [99]. They are supplied to the foetus against a concentration gradient through an energy-dependent stereospecific active transport. Except in mares, where no 
overall foeto-maternal gradient in amino acids was found [100], the plasma level of most of the amino acids is 2- to 3-fold higher in the foetus than in the dam, whereas glutamic and aspartic acid concentrations are higher in maternal blood and only slowly transferred to the foetus [101, 102]. The transfer from the mother of the essential amino acids is indispensable. It is the same for the amino acids the foetus is unable to synthesise in sufficient amounts, like cysteine in primates, because of the absence of cystathionase activity in foetal tissues [103], histidine and tyrosine [104]. All the amino acids are not transported in a similar manner by the placenta. Lemons et al. [105] measured the whole blood concentrations of 22 amino acids in foetal lambs during the last third of pregnancy. There was no umbilical uptake of the acidic amino acids glutamate, aspartate and taurine, and even a net flux of glutamate out of the foetus to the placenta was observed. This indicates that the acidic amino acids are formed within the lamb foetus (Fig. 5). Bell et al. [106] showed that there was also a relatively large flux of serine from the foetal lamb to the placenta at mid-gestation, but not in late gestation. Schneider et al. [101] reported that aspartate and glutamate were transferred to the maternal side by perfusing the human placenta on the foetal side. The impermeability of the placenta to glutamate was shown in rats [107] and in the rhesus monkey [108]. Finally, no significant uterine uptake of acidic amino acids was found in the pig [10]. In contrast, the neutral and basic amino acids are transported from the placenta to the ovine foetus, the uptake of some of which (valine, leucine, isoleucine, arginine, phenylalanine and tyrosine) is in considerable excess of the foetal requirements for growth [105] (Fig. 6). Duée et al. [10] estimated that uterine amino acid extraction was twice as high in the pig as in the sheep [109]. This difference may be

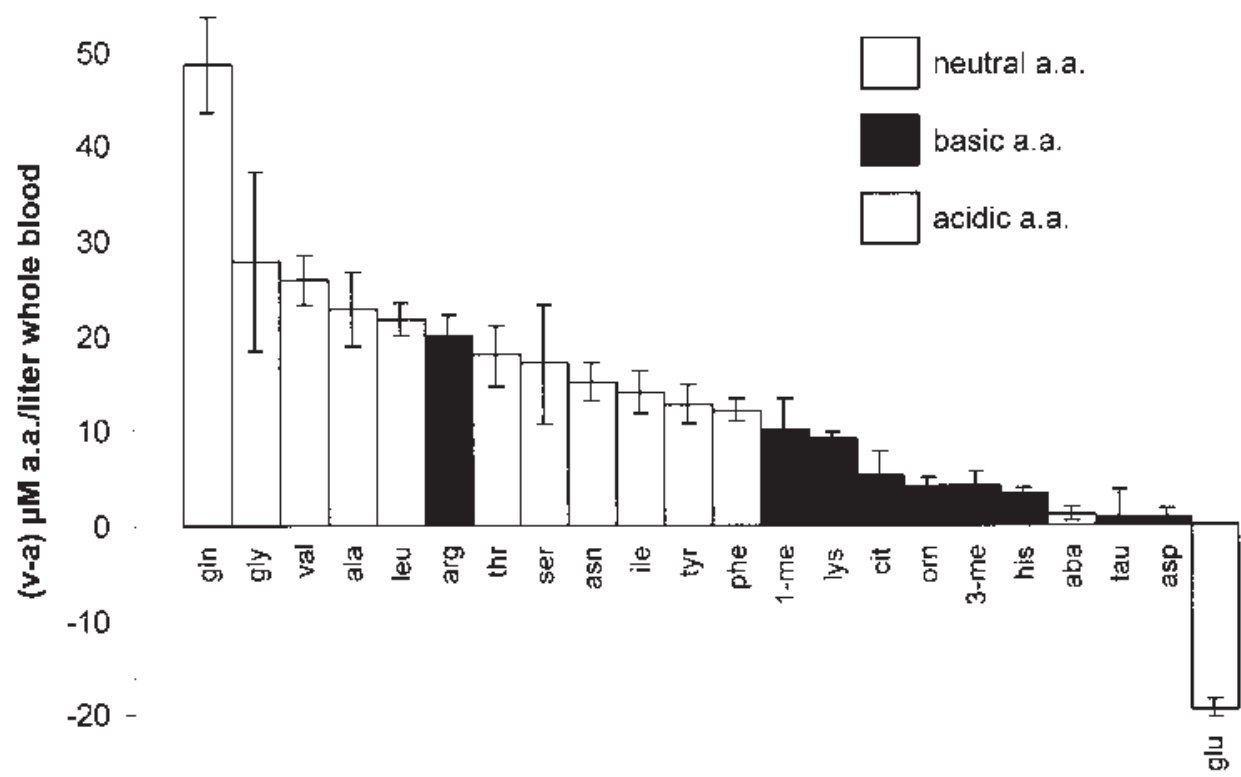

Figure 5. Mean umbilical venous arterial concentration differences of the individual amino acids in the foetal lamb [105]. 


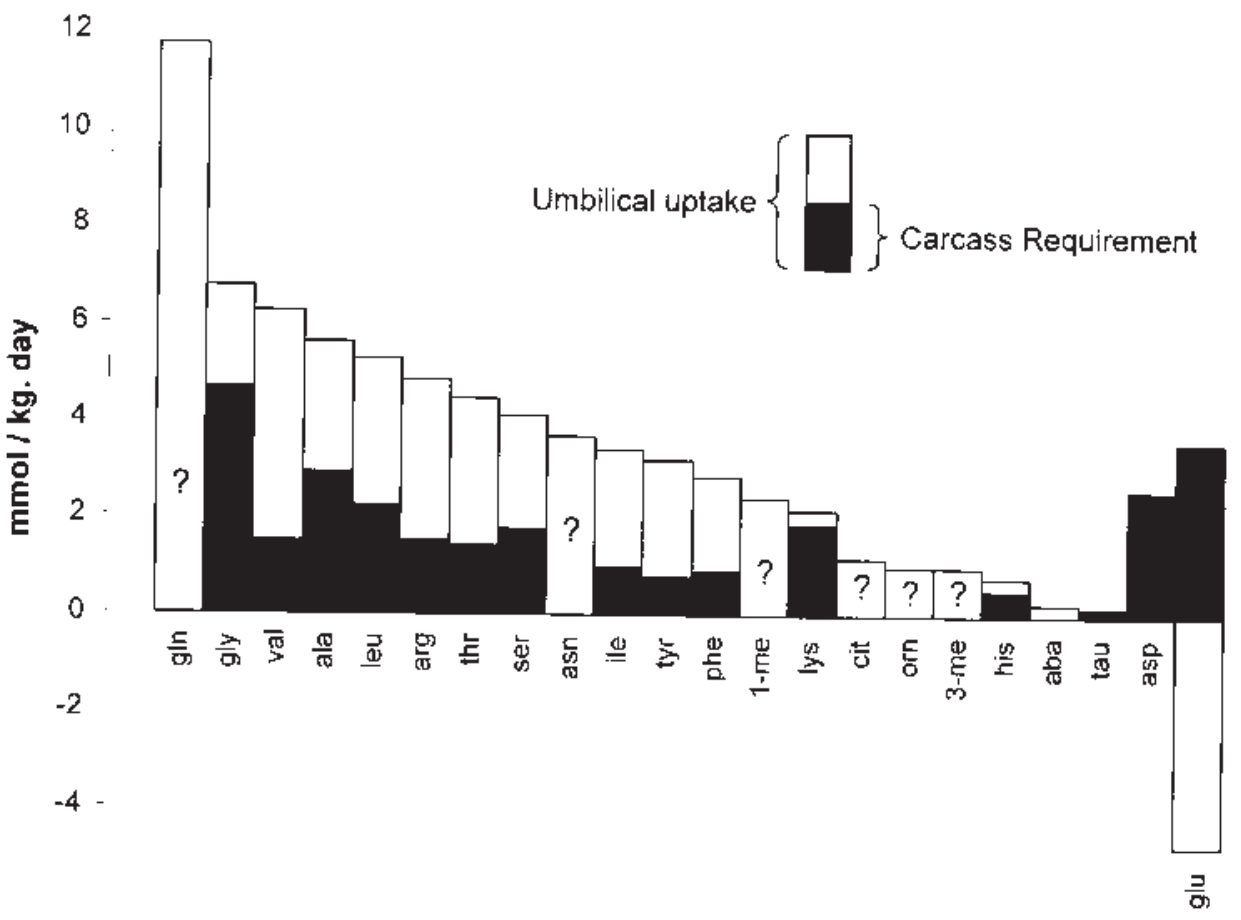

Figure 6. Comparison of the estimated carcass requirements with estimated mean umbilical uptakes of each amino acid in the ovine foetus [105].

explained by the twice as high rate of protein accretion in foetal tissues in the pig as in lambs [10].

The amino acids transferred to the foetus are not only utilised in the formation of new tissues, but they are partly used as energetic fuels through oxidative metabolism. This appears from the fact that many amino acids delivered to the ovine foetus exceed those required for growth. Higher levels of plasma urea in the foetus than in the mother in several species (sheep [110], humans [111], cows [112], pigs [26]), and the important foetal urea production exceeding neonatal or adult rates per kg weight [110, 111] also support this view. Moreover, the rabbit uterus [113] and ovine placenta [106, $114]$ are net producers of ammonia which is transferred to the foetus. Urea production by the foetal lamb corresponds to about $25 \%$ of its oxygen consumption $[110,115]$, and maternal starvation transitorily increases the urea production rate to a level twice the fed state values [116]. In cows as well, amino acids are an important oxidative substrate, since 30 to $50 \%$ of the $\alpha$-amino nitrogen is catabolised to urea by the gravid uterus $[25$, 117], and amino acids contribute to about $25 \%$ of foetal oxidative metabolism [24]. Amino acids are much less involved in the oxidative metabolism of non-ruminants. According to the amount of urea excreted by the foetus, $10 \%$ of the energy only is derived from amino acids in the human foetus [111]. Urea production by the foetal foal is only one-half the rate observed in sheep at a similar stage of gestation [32, 33]. Low concentrations of urea in utero and of total $\alpha-\mathrm{N}$ nitrogen in the foetus are found in the pig [34], and only $13 \%$ of the $\alpha$-amino nitrogen taken up by the porcine gravid uterus is catabolised to urea [27], 
suggesting that amino acids are poorly oxidised in this species [10]. This agrees with the higher contribution of carbohydrates to oxidative metabolism in the pig than in other species.

\section{CONCLUSION}

This review shows that several features of uterine and foetal metabolism are the same among mammalian species. Glucose is the main energetic substrate of the foetus, followed by lactate. The oxidation of amino acids also significantly contributes to the energy balance of the foetus. Lactate and fructose are produced from glucose by the placenta. The acidic amino acids are synthesised by the foetus, and there is a net flux of glutamate from the foetus to the placenta. There are however important differences between species, mainly linked to the differences in the structure of their placenta and sometimes to particularities of their metabolism. The contribution of lactate and amino acids to the oxidative metabolism of the human foetus is minimal. In humans like in rodents and rabbits, fatty acids and ketone bodies readily cross the placental barrier. Fatty acids are mainly incorporated in the tissue lipids, whereas ketone bodies are an alternate energy source to glucose. Triglycerides are also transferred after hydrolysis across the placenta. Glycerol uptake by foetuses from rats and guinea-pigs has also been demonstrated. In ruminants, the energy requirements of the foetus are met by glucose, lactate and amino acid oxidation, and to a lower extent by acetate. In mares and sows, the contribution of glucose to foetal oxidative metabolism is higher than in ruminants, but that of amino acids is lower. In the pig foetus, oxidation of amino acids in fact seems to be very low, whereas the contribution of lactate is higher than in the other studied mammals. By contrast to the species with an haemochorial placenta, the transfer of fatty acids to the foetuses of ruminants, horses and pigs is very low.

\section{REFERENCES}

[1] Salmon-Legagneur E. Prenatal development in the pig and some other multiparous animals. In: Lodge GA, Lamming GE (Eds), Growth and development of mammals, Butterworths, London, 1968, p 158-191.

[2] Elliott JI, Lodge GA. Body composition and glycogen reserves in the neonatal pig during the first 96 hours postpartum. Can J Anim Sci 1977, 57: 141-150.

[3] Père MC, Etienne M. Uterine blood flow in sows: effects of pregnancy stage and litter size. Reprod Nutr Dev 2000, 40: 369-382.

[4] Johnson LW, Smith CH. Identification of the glucose transport protein of the microvillous membrane of human placenta by photoaffinity labelling. Biochem Biophys Res Commun 1982, 109: 408-413.

[5] Widdas WF, Transport mechanisms in the foetus. Br Med Bull 1961, 17: 107-111.

[6] Hay WW, Meznarich HK. Effect of maternal glucose concentration on uteroplacental glucose consumption and transfer in pregnant sheep (42830). Proc Soc Exp Biol Med 1989, 190: 63-69.

[7] Bell AW, Hay WW, Ehrhardt RA. Placental transport of nutrients and its implications for fetal growth. J Reprod Fertil Suppl 1999, 54: 401-410.

[8] Illsley NP. Glucose transporters in the human placenta. Placenta 2000, 21: 14-22.

[9] Xing AY, Challier JC, Lepercq J, Cauzac M, Charron MJ, Girard J, Hauguel-de Mouzon S. Unexpected expression of glucose transporter 4 in villous stromal cells of human placenta. J Clin Endocrinol Metab 1998, 83: 4097-4101.

[10] Duée PH, Simoes Nunes C, Pégorier JP, Gilbert M, Girard J. Uterine metabolism of the conscious gilt during late pregnancy. Pediatr Res 1987, 22: 587-590.

[11] Père MC. Maternal and fetal blood levels of glucose, lactate, fructose, and insulin in the conscious pig. J Anim Sci 1995, 73: 2994-2999.

[12] Randall GCB. Daily changes in the blood of conscious pigs with catheters in foetal and uterine vessels during late gestation. J Physiol 1977, 270: 719-731.

[13] Père MC. Effects of meal intake on maternofoetal exchanges of glucose in the pig, In: Laplace JP, Février C, Barbeau A (Eds), Digestive physiology in pigs. EAAP Publication $\mathrm{N}^{\circ} 88,1997, \mathrm{p} 180-184$.

[14] Boyd RD, Morris FH, Meschia E, Makowski L, Battaglia FC. Growth of glucose and oxygen uptakes by fetuses of fed and starved ewes. Am J Physiol 1973, 225: 897-902. 
[15] Hay WW, Sparks JW, Wilkening RB, Battaglia FC, Meschia G. Fetal glucose uptake and utilization as functions of maternal glucose concentration. Am J Physiol 1984, 246: E237-E242.

[16] DiGiacomo JE, Hay WW. Fetal glucose metabolism and oxygen consumption during sustained hypoglycemia. Metabolism 1980, 39: 193-202.

[17] Battaglia FC, Meschia G. Principal substrates of fetal metabolism. Physiol Rev 1978, 58: 499527.

[18] Bassett JM, Madill D. The influence of maternal nutrition on plasma hormones and metabolites concentrations of fetal lambs. J Endocrinol 1974, 61: 465-477.

[19] Simmons MA, Battaglia FC, Meschia G. In vivo effect of insulin on fetal glucose utilization and transplacental glucose transport. Pediatr Res 1978, 12: 90-92.

[20] DiGiacomo JE, Hay WW. Placental-fetal glucose exchange and placental glucose consumption in pregnant sheep. Am J Physiol 1990, 258: E360-E367.

[21] Battaglia FC, Meschia G. An introduction to fetal physiology. Academic Press Inc., New York, 1986.

[22] Hay WW, Sparks JW, Wilkening RB, Battaglia FC, Meschia G. Partition of maternal glucose production between conceptus and maternal tissues in sheep. Am J Physiol 1983, 245: E347-E350.

[23] Meschia G, Battaglia FC, Hay WW, Sparks JW. Utilization of substrates by the ovine placenta in vivo. Fed Proc 1980, 39: 245-249.

[24] Ferrell CL, Reynolds LP. Uterine and umbilical blood flows and net nutrient uptake by fetuses and uteroplacental tissues of cows gravid with either single or twin fetuses. J Anim Sci 1992, 70: 426-433.

[25] Ferrell CL, Ford SP, Prior RL, Christenson RK. Blood flow, steroid secretion and nutrient uptake of the gravid bovine uterus and fetus. J Anim Sci 1983, 56: 656-667.

[26] Reynolds LP, Ford SP, Ferrell CL. Blood flow and steroid and nutrient uptake of the gravid uterus and fetus of sows. J Anim Sci 1985, 61: 968-974.

[27] Ford SP, Reynolds LP, Ferrell CL. Blood flow, steroid secretion and nutrient uptake of the gravid uterus during the peripartum period in sows. J Anim Sci 1984, 59: 1085-1091.

[28] James EJ, Raye JR, Gresham EL, Makowski EL, Meschia G, Battaglia FC. Fetal oxygen consumption, carbon dioxide production, and glucose uptake in a chronic sheep preparation. Pediatrics 1972, 40: 361-371.

[29] Bell AW, Kennaugh JM, Battaglia FC, Makowski EL, Meschia G. Metabolic and circulatory studies of fetal lamb at mid gestation. Am J Physiol 1986, 250: E538-E544.

[30] Tsoulos NG, Colwill JR, Battaglia FC, Makowski EL, Meschia G. Comparison of glucose, fructose, and $\mathrm{O}_{2}$ uptakes by fetuses of fed and starved ewes. Am J Physiol 1971, 221: 234-237.

[31] Comline RS, Silver M. Some aspects of foetal and utero-placental metabolism in cows with indwelling umbilical uterine vascular catheters. J Physiol 1976, 260: 571-586.

[32] Silver M, Comline RS. Transfer of gases and metabolites in the equine placenta: a comparison with other species. J Reprod Fertil 1975, 23 (Suppl): 589-594.

[33] Fowden AL, Silver M. Glucose and oxygen metabolism in the fetal foal during late gestation. Am J Physiol 1995, 269: R1455-R1461.

[34] Fowden AL, Forhead AJ, Silver M, MacDonald AA. Glucose, lactate and oxygen metabolism in the fetal pig during late gestation. Exp Physiol 1997, 82: 171-182.

[35] Fowden AL, Silver M. The effect of thyroid hormones on oxygen and glucose metabolism in the sheep fetus during late gestation. J Physiol 1995, 482: 203-213.

[36] Hay WW, Myers SA, Sparks JW, Wilkening RB, Meschia G, Battaglia FC. Glucose and lactate oxidation rates in the fetal lamb. Proc Soc Exp Biol Med 1983, 173: 553-563.

[37] Hay WW, Sparks JW, Quissell BJ, Battaglia FC, Meschia G. Simultaneous measurements of umbilical uptake, fetal utilization rate and fetal turnover rate of glucose. Am J Physiol 1981, 240: E662-E668.

[38] DiGiacomo JE, Hay WW. Regulation of placenta glucose transfer and consumption by fetal glucose production. Pediatr Res 1989, 25: 429-434.

[39] Hodgson JC, Mellor DJ, Field AC. Foetal and maternal rates of glucose production and utilization in chronically catheterized ditocous ewes. Biochem J 1981, 196: 179-186.

[40] Townsend SF, Rudolph CD, Rudolph AM. Cortisol induces perinatal hepatic gluconeogenesis in the lamb. J Dev Physiol 1991, 16: 71-79.

[41] Levitsky LL, Paton JB, Fisher DE. Gluconeogenesis from lactate in the chronically catheterized baboon fetus. Biol Neonate 1986, 50: 97-106.

[42] Gilbert M. Origin and metabolic fate of glycerol in the rat and rabbit fetus. Pediatr Res 1977, 11: 95-99.

[43] Fowden AL, Mijovic J, Ousey JC, McGladdery A, Silver M. The development of gluconeogenic enzymes in the liver and kidney of fetal and newborn foals. J Dev Physiol 1992, 18: 137-142. 
[44] Fowden AL, Apatu RS, Silver M. The glucogenic capacity of the fetal pig: developmental regulation by cortisol. Exp Physiol 1995, 80: 457-467.

[45] Leturque A, Haughel S, Ferré P, Girard J. Glucose metabolism in pregnancy. Biol Neonate 1987, 51: 64-69.

[46] Simoes-Nunes C, Duée PH, Pégorier JP, Rérat A. Effect of feed intake level in late gestation on arterial blood concentrations of energy substrates, insulin and glucagon in the chronically catheterized gilt. Reprod Nutr Dev 1987, 27: 77-87.

[47] Père MC, Etienne M, Dourmad JY. Adaptations of glucose metabolism in multiparous sows: Effects of pregnancy and feeding level. J Anim Sci 2000, 78: 2933-2941.

[48] Leturque A, Ferré P, Burnol AF, Kandé J, Maulard P, Girard J. Glucose utilization rates and insulin sensitivity in vivo in tissues of virgin and pregnant rats. Diabetes 1986, 35: 172-177.

[49] Leturque A, Burnol AF, Ferré P, Girard J. Pregnancy-induced insulin resistance in the rat: Assessment by glucose clamp technique. Am J Physiol 1984, 246: E25-E31.

[50] Hauguel S, Gilbert M, Girard J. Pregnancy induced insulin resistance in liver and skeletal muscles of the conscious rabbit. Am J Physiol 1987, 252: E165-E169.

[51] Ezekwe MO, Martin RJ. Influence of maternal alloxan diabetes or insulin injections on fetal glycogen reserves, muscle and liver development of pigs (Sus domesticus). J Anim Sci 1978, 47: 1121-1127.

[52] Ezekwe MO, Martin RJ. The effect of maternal alloxan diabetes on body composition, liver enzymes and metabolism and serum metabolites and hormones of fetal pigs. Horm Metab Res 1980, 12: 136-139.

[53] Hausman GJ, Kasser TR, Martin RJ. The effect of maternal diabetes and fasting on fetal adipose tissue histochemistry in the pig. J Anim Sci 1982, 55: 1343-1350.

[54] Kasser TR, Martin RJ, Allen CE. Effect of gestational alloxan diabetes and fasting on fetal lipogenesis and lipid deposition in pigs. Biol Neonate 1981, 40: 105-112.

[55] Ezekwe MO, Ezekwe EI, Sen DK, Ogolla F. Effects of maternal streptozotocin diabetes on fetal growth, energy reserves and body composition of newborn pigs. J Anim Sci 1984, 59: 974-980.

[56] Kasser TR, Gahagan JH, Martin RJ. Fetal hormones and neonatal survival in response to altered maternal serum glucose and free fatty acid concentrations in pigs. J Anim Sci 1982, 55: 1351-1359.

[57] Burd LI, Jones MD, Simmons MA, Makowski EL, Meschia G, Battaglia FC. Placental production and foetal utilisation of lactate and pyruvate. Nature 1975, 254: 710-711.

[58] Char VC, Creasy RK. Lactate and pyruvate as fetal metabolic substrates. Pediatr Res 1976, 10: 231-234.

[59] Christenson RK, Prior RL. Uterine blood flow and nutrient uptake during late gestation in ewes with different number of fetuses. J Anim Sci 1978, 46: 189-200.

[60] Sparks JW, Hay WW, Bonds D, Meschia G, Battaglia FC. Simultaneous measurements of lactate turnover and umbilical lactate uptake in the fetal lamb. J Clin Invest 1982, 70: 179-192.

[61] Père MC. Effects of meal intake on maternofoetal exchanges of energetic substrates in the pig. Reprod Nutr Dev 2001, 41: 285-296.

[62] Susa JB. Methodology for the study of metabolism: animal modes. In: Cowett RM (Ed), Principles of perinatal-neonatal metabolism, SpringerVerlag, New-York, 1991, p 48-60.

[63] Randall GCB, L'Ecuyer CL. Tissue glycogen and blood glucose and fructose levels in the pig fetus during the second half of gestation. Biol Neonate 1976, 28: 74-82.

[64] Silver M, Comline RS. Fetal and placental $\mathrm{O}_{2}$ consumption and the uptake of different metabolites in the ruminant and horse during late gestation. In: Grote J, Reneau D, Thews G (Eds). Advances in experimental medicine and biology, Oxygen transport to tissue II, Plenum Press, New York, 1976, p 731-736.

[65] White CE, Piper EL, Noland PR, Daniels LB. Fructose utilization for nucleic acid synthesis in the fetal pig. J Anim Sci 1982, 55: 73-76.

[66] Ballard FJ, Oliver IT. Carbohydrate metabolism in liver from fetal and neonatal sheep. Biochem J 1965, 95: 191-200.

[67] Meznarich HK, Hay WW, Sparks JW, Meschia G, Battaglia FC. Fructose disposal and oxidation rates in the ovine fetus. Q J Exp Physiol 1987, 72: 617-625.

[68] Crawford MA, Williams G, Hassam AG. Essential fatty acids and fetal brain growth. Lancet 1976, 1: 452-453.

[69] Elphick MC, Hull D, Broughton Pipkin F. The transfer of fatty acids across the sheep placenta. J Dev Physiol 1979, 1: 31-45.

[70] Pethick DW, Lindsay DB, Parker PJ, Northrop AJ. The metabolism of circulating non-esterified fatty acids by the whole animal, hind-limb muscle and uterus of pregnant ewes. Br J Nutr 1983, 49: 129-143.

[71] Leat WMF, Harrison F. Transfer of long-chain fatty acids to the fetal and neonatal lamb. J Dev Physiol 1980, 2: 257-274.

[72] Van Duyne CM, Parker HR, Havel RJ, Holm LM. Free fatty acid metabolism in fetal and newborn sheep. Am J Physiol 1960, 199: 987-990. 
[73] Elphick MC, Flecknell P, Hull D, Mc Fayden IR. Plasma free fatty acid umbilical venous-arterial concentration differences and placental transfer of $\left[{ }^{14} \mathrm{C}\right]$ palmitic acid in pigs. J Dev Physiol 1980, 2: 347-356.

[74] Thulin AJ, Allee GL, Harmon DL, Davis DL. Utero-placental transfer of octanoic, palmitic and linoleic acids during late gestation in gilts. J Anim Sci 1989, 67: 738-745.

[75] Martin RJ, Hausman GJ. Placental development and fatty acid metabolism in pigs fed ad libitum or restricted during gestation. Proc Soc Exp Biol Med 1981, 166: 472-478.

[76] Ramsay TG, Kasser TR, Hausman GJ, Martin RJ. Metabolic development of the porcine placenta in response to alterations in maternal or fetal homeostasis. In: Tumbleson EM (Ed) Swine in biochemical research Vol. 2, Plenum Press, New York, 1986, p 1325-1337.

[77] Ruwe PJ, Wolverton CK, White ME, Ramsay TG. Effect of maternal fasting on fetal and placental lipid metabolism in swine. J Anim Sci 1991, 69: 1935-1944.

[78] Seerley RW, Pace TA, Foley CW, Scarth RD. Effect of energy intake prior to parturition on milk lipids and survival rate, thermostability and carcass composition of piglets. J Anim Sci 1974, 38: 64-70.

[79] Gerfault V, Mourot J, Etienne M, Mounier A. Influence de la nature des lipides dans le régime de gestation de la truie sur ses performances et la composition des porcelets à la naissance. J Rech Porcine en France 1999, 31: 191-197.

[80] Char VC, Creasy RK. Acetate as a metabolic substrate in the fetal lamb. Am J Physiol 1976, 230: 357-361.

[81] Edson JL, Hudson DG, Hull D. Evidence for increased fatty acid transfer across the placenta during a maternal fast in rabbits. Biol Neonate 1975, 27: 50-55.

[82] Elphick MC, Hudson DG, Hull D. Transfer of fatty acids across the rabbit placenta. J Physiol 1975, 252: 29-42.

[83] Gilbert M, Hauguel S, Bouisset M. Uterine blood flow and substrate uptake in conscious rabbit during late gestation. Am J Physiol 1984, 247: E574-E580.

[84] Stephenson TJ, Stammers JP, Hull D. Effects of altering umbilical flow and umbilical free fatty acid concentration on transfer of free fatty acids across the rabbit placenta. J Dev Physiol 1991, 15: 221-227.

[85] Thomas CR, Lowy C. The clearance and placental transfer of free fatty acids and triglycerides in the pregnant guinea-pig. J Dev Physiol 1982, 4: 163-173.

[86] Thomas CR, Lowy C. Placental transfer of free fatty acids: factors affecting transport across the guinea-pig placenta. J Dev Physiol 1983, 5: 323-332.

[87] Hummel L, Schirrmeister W, Wagner H. Quantitative evaluation of the maternal-fetal transfer of free fatty acids in the rat. Biol Neonate 1975, 26: 263-267.

[88] Koren L, Shafrir E. Placental transfer of free fatty acids in pregnant rats. Proc Soc Exp Biol Med 1964, 116: 411-414.

[89] Shafrir E, Khassis S. Maternal-fetal fat transport versus new fat synthesis in the pregnant diabetic rat. Diabetologia 1982, 22: 111-117.

[90] Portman OW, Behrman RE, Soltys P. Transfer of free fatty acids across the primate placenta. Am J Physiol 1969, 216: 143-147.

[91] Dancis J, Janses V, Levitz M. Transfer across perfused human placenta. IV Effect of protein binding in free fatty acids. Pediatr Res 1976, 10: 5-10.

[92] Sabata V, Wolf H, Lausmann S. The role of free fatty acids, glycerol, ketone bodies and glucose in the energy metabolism of the mother and fetus during delivery. Biol Neonate 1968, 13: 7-17.

[93] Szabo AJ, Grimaldi RD, Jung WF. Palmitate transport across perfused human placenta. Metabolism 1969, 18: 406-415.

[94] Girard J, Pintado E, Ferré P. Fuel metabolism in the mammalian fetus. Ann Biol Anim Biochim Biophys 1979, 19: 181-197.

[95] Thomas CR, Lowy C. The interrelationships between circulating maternal esterified and non-esterified fatty acids in pregnant guinea-pigs, and their relative contributions to the fetal circulation. J Dev Physiol 1987, 9: 203-214.

[96] Shafrir E, Barash V. Placental function in maternal-fetal fat transport in diabetes. Biol Neonate 1987, 51: 102-112.

[97] Elphick MC, Hull D. Rabbit placental clearing-factor lipase and transfer to the foetus of fatty acids derived from triglycerides injected into the mother. J Physiol 1977, 273: 475-487.

[98] Mallov S, Alousi AA. Lipoprotein lipase activity of rat and human placenta. Proc Soc Exp Biol Med 1965, 119: 301-306.

[99] Young M, Hill PMM. Free amino acid transfer across the placental membrane, In: Comline KS, Cross KW, Dawes GS, Nathanielsz PW (Eds), Foetal and neonatal physiology, Barcroft centenary symposium, Cambridge University Press, London, 1973, p 329-338.

[100] Silver M, Fowden AL, Taylor PM, Knox J, Hill CM. Blood amino acids in the pregnant mare and fetus: the effects of maternal fasting and intrafetal insulin. Exp Physiol 1994, 79: 423-433.

[101] Schneider H, Möhlen KH, Dancis J. Transfer of amino acids across in vitro perfused human placenta. Pediatr Res 1979, 13: 236-240. 
[102] Young M, McFadyen IR. Placental transfer and fetal uptake of amino acids in the pregnant ewe. $\mathrm{J}$ Perinat Med 1973, 1: 174-182.

[103] Gaull GE, Sturman JA, Räihä NCR. Development of mammalian sulphur metabolism: absence of cystathionase in human fetal tissues. Pediatr Res 1972, 6: 538-547.

[104] Kenney FT, Reem GH, Kretchmer N. Development of phenylalanine hydroxylase in mammalian liver. Science 1958, 127: 86.

[105] Lemons JA, Adcock III EW, Jones MD, Naughton MA, Meschia G, Battaglia FC. Umbilical uptake of amino acids in the unstressed fetal lamb. J Clin Invest 1976, 58: 1428-1434.

[106] Bell AW, Kennaugh JM, Battaglia FC, Meschia G. Uptake of amino acids and ammonia at mid gestation by the fetal lamb. Q J Exp Physiol 1989, 74: 635-643.

[107] Dierks-Ventling C, Cone AL, Wapnir RA. Placental transfer of amino acids in the rat. I. l-glutamic acid and l-glutamine. Biol Neonate 1971, 17: 361-372.

[108] Stegink LD, Pitkin RM, Reynolds WA, Filer LJ, Boaz DP, Brummel MC. Placental transfer of glutamate and its metabolites in the primate. Am J Obstet Gynecol 1975, 122: 70-78.

[109] Holzman IR, Lemons JA, Meschia G, Battaglia FC. Uterine uptake of amino acids and placental glutamine-glutamate balance in the pregnant ewe. J Dev Physiol 1979, 1: 137-149.
[110] Gresham EL, James EJ, Raye JR, Battaglia FC, Makowski EL, Meschia G. Production and excretion of urea by the fetal lamb. Pediatrics 1972 , 50: 372-379.

[111] Gresham EL, Simons PS, Battaglia FC. Maternal-fetal urea concentration difference in man: metabolic significance. J Pediatrics 1971, 79: 809-811.

[112] Ferrell CL. Maternal and fetal influences on uterine and conceptus development in the cow. II. Blood flow and nutrient flux. J Anim Sci 1991, 69: 1954-1965.

[113] Johnson RL, Gilbert M, Block SM, Battaglia FC. Uterine metabolism of the pregnant rabbit under chronic steady state conditions. Am J Obstet Gynecol 1986, 154: 1146-1151.

[114] Holzman IR, Lemons JA, Meschia G, Battaglia FC. Ammonia production by the pregnant uterus. Proc Soc Exp Biol Med 1977, 156: 27-30.

[115] Lemons JA, Schreiner RL. Amino acid metabolism in the ovine fetus. Am J Physiol 1983, 244: E459-E466.

[116] Simmons MA, Meschia G, Makowski EL, Battaglia FC. Fetal metabolic response to maternal starvation. Pediatr Res 1974, 8: 830-836.

[117] Ferrell CL, Ford SP. Blood flow, steroid secretion and nutrient uptake of the gravid bovine uterus. J Anim Sci 1980, 50: 1113-1121. 
